\title{
Evaluation of biopesticides against coconut perianth mite $A$. guerreronis Keifer under laboratory conditions
}

\author{
K. BALAJI* AND Y. HARIPRASAD \\ Department of Entomology, Annamalai University, CHIDAMBARAM (T.N.) INDIA
}

\section{ARITCLE INFO}

Received : 21.01.2016

Accepted : 24.03.2016

\section{KEY WORDS :}

Coconut mite, A. guerreronis, Bio pesticides, Bioassay

\begin{abstract}
A laboratory experiment was conducted at Department of Agricultural Entomology, Annmalai University, Chidambaram to know the efficacy of some pesticides and biopesticides against A.guerreronis. The treatments used were Phytopalm $1.5 \mathrm{~g}$, Phytopalm 1g, Neem azal 1 per cent, Fortune aza 1.5 per cent, Neem Seed Kernel Extract 5 per cent, Neem oil 3 per cent, Nochi leaf extract 3 per cent, Calotrpis leaf extract 5 per cent. For comparing the efficacy of selected botanicals and monocrotophos 0.04 per cent was used as treated check in Randomized Block Design with five replications.

How to view point the article : Balaji, K. and Hariprasad, Y. (2016). Evaluation of biopesticides against coconut perianth mite $A$. guerreronis Keifer under laboratory conditions. Internat. J. Plant Protec., 9(1) : 329-332.
\end{abstract}

